\title{
Tuber Rot of Potato Caused by Phytophthora nicotianae: Isolate Aggressiveness and Cultivar Susceptibility
}

Raymond J. Taylor and Julie S. Pasche, Department of Plant Pathology, North Dakota State University, Fargo, ND 58105; H. David Shew and K. R. Lannon, Department of Plant Pathology, North Carolina State University, Raleigh, NC 27695; and Neil C. Gudmestad, Department of Plant Pathology, North Dakota State University, Fargo, ND 58105

\begin{abstract}
Taylor, R. J., Pasche, J. S., Shew, H. D., Lannon, K. R., and Gudmestad, N. C. 2012. Tuber rot of potato caused by Phytophthora nicotianae: Isolate aggressiveness and cultivar susceptibility. Plant Dis. 96:693-704.

A study was undertaken in 2008 and 2009 to examine potato (Solanum tuberosum) cultivar susceptibility, the potential of other host species to act as sources of inoculum for potato infections, and other aspects of potato-Phytophthora nicotianae interactions. Twelve isolates of $P$. nicotianae collected from five leaf, one petiole, and six tuber infections of potato from five states, as well as isolates from a variety of other host species, were evaluated for ability to cause tuber rot of potato via inoculation studies. Additionally, the susceptibility of 27 potato cultivars commonly grown in the United States to tuber infection by $P$. nicotianae was determined. Eighty-three percent of the isolates recovered from potato were highly aggressive, infecting tubers at nearly four times greater incidences than isolates originating from nonpotato hosts.

With the exception of two tobacco isolates, zoospores of all isolates recovered from nonpotato hosts were able to infect potato tubers. Russet cultivars were significantly less susceptible to $P$. nicotianae than red and white cultivars in 2008, and red cultivars in 2009. Umatilla Russet was the most resistant cultivar in both years, whereas Red Norland and Dakota Rose were the most susceptible in both years. Results of a survey for $P$. nicotianae conducted in four states from 2008 through 2010 confirmed previous observations of naturally occurring infections of potato in Missouri, Nebraska, and Texas, as well as infections of potato in Michigan (documented for the first time). All isolates recovered in the survey were sensitive to mefenoxam $\left(\mathrm{EC}_{50}<1.0\right.$ $\mu \mathrm{g} / \mathrm{ml})$.
\end{abstract}

The potato (Solanum tuberosum L.) has become a major food crop, ranking fourth behind wheat, maize, and rice in importance as a staple (47). As the popularity and range of production and consumption has increased, so has the realization that the potato plant is susceptible to a myriad of diseases that affect virtually every tissue and organ. Although damage to aboveground plant tissues by diseases can be substantial, pathogens that attack the belowground starch storage organ may have the most profound effect upon yield, and ultimately, storability and quality of the crop $(13,30,36)$. Several species of fungi and oomycetes, representing a broad group of genera, are known to cause tuber rots of the cultivated potato $(6,40)$. In North America, dry rot (Fusarium solani (Mart.) Sacc. and F. sambucinum Fuckel) (37), gray mold (Botrytis cinerea Pers.:Fr.) (29), leak (Pythium ultimum Trow) (32), late blight (Phytophthora infestans (Mont.) de Bary) (9), and pink rot (Phytophthora erythroseptica Pethybr.) (16) are among the most common of these diseases, and each can have an economic impact in a growing season. Of these, the latter two are very destructive and, therefore, could be considered the most important tuber rot diseases in nearly all potato production areas $(9,13,16,30,36)$. Late blight tuber infections can be devastating, but generally are acute and do not cause economic losses on an annual basis (13). On the other hand, $P$. erythroseptica is ubiquitous and endemic in virtually every potato growing region; therefore, pink rot can be a chronic problem for producers, who often experience economic losses from this disease $(13,16,30,36)$.

Pink rot first was described as a potato tuber disease in Ireland in 1913 (27) and has been known to occur in North America since 1938 (1). It has become one of the most important soilborne tuber

Corresponding author: Neil C. Gudmestad,

E-mail: Neil.Gudmestad@ndsu.edu

Accepted for publication 19 November 2011.

http://dx.doi.org/10.1094/PDIS-01-11-0037

(C) 2012 The American Phytopathological Society diseases of potato in the United States in recent years $(13,36)$. Although $P$. erythroseptica generally is considered to be the principal cause of the disease $(1,3,11,16,27)$, several other Phytophthora species have been shown, via inoculation studies, to infect potato tubers and produce pink rot-like symptoms (6). Other Phytophthora spp., including $P$. drechsleri Tucker (4), P. megasperma Drechs. (3), P. cryptogea Pethybr. \& Lafferty $(12,19,31)$, and $P$. nicotianae van Breda de Haan (synonym $=P$. parasitica) $(12,22,41)$, have been isolated from naturally occurring tuber infections, but none has been considered a significant potato pathogen.

$P$. nicotianae is capable of infecting a large range of hosts, including over 300 plant species (6). Among the most notable diseases attributed to this pathogen are brown rot, foot rot, and black shank of tobacco, as well as gummosis and root rot of citrus species. The pathogen is a recurring problem in greenhouse and nursery settings, commonly resulting in root and crown rots of annual herbaceous and perennial woody plant species. $P$. nicotianae has been reported to cause foliar blight and pink tuber rot of potato $(4,6,12,22,26)$ but previously was not considered to be a major threat to the potato crop. The number of recently confirmed cases of foliar and tuber infections of potato caused by P. nicotianae (41) suggests that this species is becoming increasingly prevalent, posing a significant threat to potato production, particularly in warmer, southern growing regions of the United States. Thirty isolates of $P$. nicotianae were recovered from naturally occurring potato infections from Florida, Nebraska, Missouri, and Texas between 2005 and 2007 (41). Such outbreaks previously were rare, with only sporadic appearances recorded in Kentucky and Oklahoma in 1929 (4), North Carolina in 1969 (26), Texas in 1983 (12), and Delaware and New Jersey in 1994 (22).

Symptoms of tuber rot caused by $P$. nicotianae are similar to those of pink tuber rot commonly caused by $P$. erythroseptica, with development of a soft, spongy, watery texture in the infected tissue $(12,41)$. However, the infected tissue often lacks the typical pink color that develops and intensifies after exposure of the cut, infected tuber surface to air, which is diagnostic of $P$. erythroseptica infections $(11,16)$. Tuber tissue infected with $P$. nicotianae usually develops a less intense, pale pink discoloration, but generally the 
color varies from a light, creamy tan to pale brown, depending upon the cultivar $(4,12,41)$. In some instances, infected tuber tissue turns dark brown to black after exposure of the cut tuber surface to air for an hour or more.

Zoospores of $P$. erythroseptica typically infect potato tubers through stolons but also may infect through eyes or lenticels to cause pink rot $(16,17,27,36)$. Pink rot also may be initiated by zoospores or mycelium penetrating tubers through cuts, cracks, or other damage to the periderm made during harvest or handling operations $(16,34)$. Little is known about the etiology and epidemiology of $P$. nicotianae tuber rot; however, it appears that the mode of infection and disease development are similar to that of common pink rot. Field observations and inoculation studies suggest that $P$. nicotianae infections are initiated through the stolons, eyes, and lenticels, similar to infections caused by $P$. erythroseptica $(12,41)$. Laboratory studies also have demonstrated that wounds may be important infection courts (41). Tuber infections were reported to nearly double following inoculation of freshly wounded tissue with zoospores of $P$. nicotianae when compared to inoculations of nonwounded eye tissue. Isolates of $P$. nicotianae obtained from natural potato tuber or foliar infections were capable of infecting both leaf and tuber tissue, regardless of the tissue from which isolates were originally recovered $(26,41)$. However, all isolates of $P$. nicotianae appeared to be less aggressive than $P$. erythroseptica isolates at infecting tuber tissue (41). As P. nicotianae infections of potato have become more prevalent, it is important to examine aggressiveness of isolates recovered from other host species, especially considering the wide host range of this pathogen (6)

Conditions of high moisture favor infection by $P$. erythroseptica and $P$. nicotianae (41). In the field, foliar infections by $P$. nicotianae commonly are concentrated in low-lying areas and along irrigator wheel tracks where compacted soil promotes the accumulation of standing water (41). Tubers produced under furrow irrigation in heavier, clay soils also are more prone to infection (12), and the pathogens readily move within the field as motile zoospores carried in irrigation water. Development of $P$. nicotianae tuber rot appears to be favored in potato-growing areas that have warmer growing seasons and where tubers are harvested when air and soil temperatures are high $(12,16,41)$. Intermittent but severe losses can occur under such conditions (12; unpublished data). Since $P$. erythroseptica and $P$. nicotianae are likely to infect potato plants in a similar manner, cultural practices and applications of mefenoxam used to manage $P$. erythroseptica $(13,23,24,30,36$, 44,49,51,52) should help control $P$. nicotianae.

Susceptibility to $P$. erythroseptica has been assessed in potato genotypes (33) and breeding lines (46), but with the exceptions of Red Norland, Russet Norkotah, Snowden, Russet Burbank, and Atlantic examined in 2008 (41), and three cultivars and four breeding lines screened in an earlier study (12), the susceptibility of potato cultivars to $P$. nicotianae generally is unknown. Potato genotypes demonstrate considerable variability in susceptibility to
P. erythroseptica $(33,42,43,46)$. Therefore, susceptibility to another species of Phytophthora is expected to range widely. Cultivar resistance could be an important component of a management strategy, particularly if mefenoxam resistance appears in the $P$. nicotianae populations responsible for potato infections. Mefenoxam (and metalaxyl) resistant strains of $P$. nicotianae have been recovered from other plant species $(7,8,14,15)$ and soil $(48)$. Since P. nicotianae has an extensive host range, it is likely that strains from other plant species are pathogenic to potato. The probability of identifying mefenoxam resistance in $P$. nicotianae potato populations remains low. Strains from those populations are not likely to have experienced extensive exposure to the fungicide since mefenoxam is not used commonly on crops typically included in potato rotations.

This study was undertaken to assess these suppositions and provide additional details regarding potato- $P$. nicotianae interactions. The specific objectives of this study were to: (i) assess the ability of $P$. nicotianae isolates from a variety of hosts to cause tuber rot in potato, (ii) determine the susceptibility of commonly grown potato cultivars to tuber infection by $P$. nicotianae, and (iii) characterize isolates of the pathogen collected during a survey in 2008, 2009, and 2010 that were not part of a previous survey (41). To achieve these objectives, pathogenicity and aggressiveness of $P$. nicotianae isolates collected from a range of hosts, host tissues, and locations were evaluated; and multiple potato cultivars were screened for susceptibility to tuber rot via postharvest tuber inoculations. Isolates obtained in the survey were characterized by determining mating type, sensitivity to mefenoxam, and identity to species via morphological observation and polymerase chain reaction (PCR) assays. Results from these studies should help improve management practices for $P$. nicotianae in potato production.

\section{Materials and Methods}

Isolate collection. As an extension of a survey (41) to assess the geographic distribution of $P$. nicotianae infections of potato, isolates were collected from pink rot outbreaks in commercial potato fields in four states in 2008, 2009, and 2010 (Table 1). A subset of the isolates evaluated in the study was selected from a collection of $P$. nicotianae isolates at North Dakota State University (Table 2). These isolates initially were recovered from naturally occurring infections of potato by transferring small pieces (approximately 25 $\mathrm{mm}^{3}$ ) of infected potato leaf, petiole, or tuber tissue to petri dishes containing water agar (1.5\% agar in deionized water). Following incubation in the dark at $20^{\circ} \mathrm{C}$ for 3 to 5 days, colonies with mycelia resembling that of $P$. nicotianae were isolated utilizing hyphal tip transfers. In addition, an isolate from potato was obtained from the collection of Robert Mulrooney, University of Delaware; tobacco isolates were obtained from H. David Shew, North Carolina State University; and Chuanxue Hong, Virginia Polytechnic Institute and State University, provided isolates of $P$. nicotianae recovered from other plant species and effluent water collected from a recycling irrigation system at a commercial container nursery pro-

Table 1. Origin, mating type, and mefenoxam sensitivity of previously uncharacterized Phytophthora nicotianae isolates recovered from potato

\begin{tabular}{|c|c|c|c|c|c|c|c|c|}
\hline \multirow{2}{*}{$\begin{array}{l}\text { Collection } \\
\text { year }\end{array}$} & \multirow[b]{2}{*}{ Location } & \multicolumn{2}{|c|}{ Number of isolates } & \multirow{2}{*}{$\begin{array}{c}\mathrm{EC}_{50}(\mathrm{mean} \pm \\
\mathrm{SD}, \mu \mathrm{g} / \mathrm{ml})^{\mathrm{z}}\end{array}$} & \multicolumn{4}{|c|}{ Number of isolates recovered } \\
\hline & & $\mathbf{A 1}^{\mathbf{y}}$ & A2y & & Leaf & Petiole & Stem & Tuber \\
\hline \multirow[t]{3}{*}{2008} & Arbyrd, MO & 0 & 6 & $0.049 \pm 0.007$ & 6 & 0 & 0 & 0 \\
\hline & Pearsall, TX & 0 & 10 & $0.051 \pm 0.006$ & 10 & 0 & 0 & 0 \\
\hline & Dalhart, TX & 0 & 7 & $0.051 \pm 0.006$ & 0 & 0 & 0 & 7 \\
\hline \multirow[t]{4}{*}{2009} & Three Rivers, MI & 0 & 7 & $0.031 \pm 0.012$ & 0 & 0 & 0 & 7 \\
\hline & Pearsall, TX & 1 & 21 & $0.079 \pm 0.055$ & 6 & 3 & 13 & 0 \\
\hline & Olton, TX & 0 & 3 & $0.057 \pm 0.007$ & 2 & 0 & 1 & 0 \\
\hline & Dalhart, TX & 0 & 7 & $0.040 \pm 0.008$ & 2 & 1 & 4 & 0 \\
\hline \multirow[t]{3}{*}{2010} & Columbus, NE & 1 & 0 & $0.100 \pm 0.073$ & 1 & 0 & 0 & 0 \\
\hline & Pearsall, TX & 0 & 9 & $0.040 \pm 0.004$ & 0 & 3 & 6 & 0 \\
\hline & Olton, TX & 0 & 5 & $0.074 \pm 0.036$ & 5 & 0 & 0 & 0 \\
\hline
\end{tabular}

\footnotetext{
y Mating type.
}

${ }^{\mathrm{z}}$ Effective mefenoxam concentration resulting in 50\% reduction of mycelial growth relative to the control treatment in which the isolates were not exposed to mefenoxam. Isolates were tested in duplicate at each fungicide concentration and the experiment was repeated. $\mathrm{SD}=$ standard deviation. 
ducing a diverse range of perennial cultivars (2) (USDA-APHIS Permit P526P-06-02040). All isolates were transferred to clarified $10 \%$ V8 juice (CV8) agar medium (100 ml V8 juice, $1 \mathrm{~g} \mathrm{CaCO}_{3}$ centrifuged at 7,000 rpm for $5 \mathrm{~min}$ using a Sorvall RC5C centrifuge to remove the pulp, $15 \mathrm{~g}$ agar, and $900 \mathrm{ml}$ deionized water) and stored in the dark at $20 \pm 1^{\circ} \mathrm{C}$ prior to testing.

Morphological characterization. Isolates of $P$. nicotianae were grown on either 5\% clarified carrot agar (CA) (50 ml Hollywood carrot juice, $950 \mathrm{ml}$ deionized water, and $20 \mathrm{~g}$ Difco Bacto agar/liter water, clarified by filtering through Celite) or 5\% CV8 agar $(50 \mathrm{ml} \mathrm{V8}$ juice, $950 \mathrm{ml}$ deionized water, and $20 \mathrm{~g}$ Difco Bacto agar, clarified by filtering through Celite), and maintained with regular transfers. Colony morphology, and vegetative and reproductive stages of growth were examined for cultures grown for 1 to 4 weeks at 20 to $25^{\circ} \mathrm{C}$ in light, using a Nikon TMS Inverted Phase Contrast Microscope. Isolates were scored for appearance of hyphae, size and shape of sporangia and chlamydospores, and presence or absence of oospores. The resulting observations were compared to published descriptions of $P$. nicotianae $(6,10)$.

DNA extraction. Mycelium of each isolate was produced in sterile pea broth by incubating petri dish cultures for 7 days at $23^{\circ} \mathrm{C}$ in the dark. Pea broth was prepared by autoclaving $120 \mathrm{~g}$ frozen peas in 1 liter deionized water, and filtering the suspension through cheesecloth. The broth was sterilized by autoclaving for an additional $30 \mathrm{~min}$ after filtering. DNA was extracted from mycelium using the CTAB (cetyl trimethyl ammonium bromide) method described in a previous study of P. nicotianae on potato (41). DNA precipitate was collected and washed three times with $100 \mu \mathrm{l}$ cold $80 \% \mathrm{EtOH}$. The pellets were dried and then suspended in $30 \mu \mathrm{l}$ nuclease-free water and stored at $4^{\circ} \mathrm{C}$. Extracted DNA was run in a $1 \%$ agarose gel to confirm the quality of the DNA. DNA concentrations were determined using a NanoDrop 1000 and diluted to $10 \mathrm{ng} / \mu \mathrm{l}$ for PCR assays.

PCR assays. Samples were amplified using species-specific primers previously described for $P$. nicotianae (5). Primer \#1 ( $5^{\prime}$ CTGACGATCCAGATCCTCTGCACG-3') was used as the forward primer, and primer \#2 (5'-CTTGCGAGGCTTGACCGC
TTCCTA-3') as the reverse primer. Amplifications were done with an Eppendorf Mastercycler thermal cycler (Eppendorf Scientific, Westbury, NY). Each reaction contained $20 \mathrm{ng}$ template DNA in sterile, nuclease-free water; $2.5 \mu \mathrm{M}$ forward primer; $2.5 \mu \mathrm{M}$ reverse primer; 10× PCR buffer; dNTPs; and Taq DNA polymerase (QIAGEN). The cycling parameters were 1 cycle at $94^{\circ} \mathrm{C}$ for 1 min; 30 cycles of $2 \mathrm{~min}$ annealing at $65^{\circ} \mathrm{C}, 3 \mathrm{~min}$ extension at $72^{\circ} \mathrm{C}$, and $1 \mathrm{~min}$ denaturation at $94^{\circ} \mathrm{C}$; followed by 1 extension cycle at $72^{\circ} \mathrm{C}$ for $10 \mathrm{~min}$. A negative control sample (without DNA) was included, and amplicons were visualized and photographed on a $1 \%$ agarose gel. PCR products were purified using the QIAquick PCR Purification Kit (QIAquick Gel Extraction Kit, QIAGEN). Purified PCR products were sent to the DNA Sequencing and Genotyping facility in the Life Sciences Core Laboratory Center at Cornell University for sequencing.

Mating type. The mating type of each of the P. nicotianae isolates was determined by pairing each isolate with known A1 and A2 isolates. Two different sets of testers were used in all pairings, and all testers were obtained from tobacco fields in NC. All mating type evaluations also included pairings of testers to confirm suitable conditions for oospore formation. Isolates were paired on CA supplemented with water-soluble cholesterol at $5 \mathrm{ppm}$, and incubated in the dark for 21 to 30 days at 20 to $24^{\circ} \mathrm{C}$. Each pairing was observed microscopically for the presence of oospores. If oospores formed when an isolate was paired with the known A1 isolate, the isolate was considered to be an A2 mating type, and vice versa. Isolates that failed to form oospores with either isolate were designated as the A0 mating type.

Mefenoxam sensitivity. Mefenoxam (Ridomil Gold 4EC; Syngenta Crop Protection, Greensboro, NC) sensitivity of the isolates was determined using an in vitro screening method similar to a technique described previously $(41,42,44,45)$. Tests were conducted on $5 \% \mathrm{CV} 8$ agar medium $(50 \mathrm{ml} \mathrm{V8}$ juice centrifuged at 7,000 rpm for $5 \mathrm{~min}$ using a Sorvall RC5C centrifuge to remove pulp, $15 \mathrm{~g}$ agar, and $950 \mathrm{ml}$ deionized water) amended with mefenoxam in a 10-fold dilution series ranging from 0.01 to 100 $\mu \mathrm{g} / \mathrm{ml}$. Agar plates not amended with mefenoxam served as the

Table 2. Identity, origin, mating type, and mefenoxam sensitivity of a collection of Phytophthora nicotianae isolates from the United States

\begin{tabular}{|c|c|c|c|c|c|}
\hline Isolate & Origin & Collection year & Mating type & $\mathrm{EC}_{50}(\operatorname{mean} \pm \mathrm{SD}, \mu \mathrm{g} / \mathrm{ml})^{\mathrm{u}}$ & Host (source tissue) \\
\hline $05 \mathrm{NE} 1-1^{\mathrm{v}}$ & Nebraska & 2005 & A2 & $0.125 \pm 0.074$ & Potato (tuber) \\
\hline $06 \mathrm{FL} 1-7^{\mathrm{v}}$ & Florida & 2006 & $\mathrm{~A} 2$ & $0.238 \pm 0.233$ & Potato (tuber) \\
\hline $06 \mathrm{NE} 1-5^{\mathrm{v}}$ & Nebraska & 2006 & A1 & $0.094 \pm 0.003$ & Potato (leaf) \\
\hline $06 \mathrm{TX} 1-3^{\mathrm{v}}$ & Texas & 2006 & $\mathrm{~A} 2$ & $0.137 \pm 0.083$ & Potato (leaf) \\
\hline $07 \mathrm{MO} 1-1^{\mathrm{v}}$ & Missouri & 2007 & A0 & $0.369 \pm 0.131$ & Potato (tuber) \\
\hline $07 \mathrm{MO} 1-3^{\mathrm{v}}$ & Missouri & 2007 & A2 & $0.068 \pm 0.004$ & Potato (tuber) \\
\hline $07 \mathrm{TX} 1-1^{\mathrm{v}}$ & Texas & 2007 & $\mathrm{~A} 2$ & $0.083 \pm 0.009$ & Potato (leaf) \\
\hline $07 \mathrm{TX} 2-1^{\mathrm{v}}$ & Texas & 2007 & A2 & $0.419 \pm 0.176$ & Potato (petiole) \\
\hline $08 \mathrm{MO} 1-2^{\mathrm{v}}$ & Missouri & 2008 & $\mathrm{~A} 2$ & $0.057 \pm 0.002$ & Potato (leaf) \\
\hline $08 \mathrm{TX} 1-9^{\mathrm{v}}$ & Texas & 2008 & A2 & $0.051 \pm 0.001$ & Potato (leaf) \\
\hline $08 \mathrm{TX} 2-1^{\mathrm{v}}$ & Texas & 2008 & $\mathrm{~A} 2$ & $0.052 \pm 0.003$ & Potato (tuber) \\
\hline $\mathrm{N} 3^{\mathrm{w}}$ & Delaware & 1995 & A2 & $0.322 \pm 0.171$ & Potato (tuber) \\
\hline Dav-Whi- $7^{x}$ & North Carolina & 2006 & A2 & $0.195 \pm 0.099$ & Tobacco \\
\hline Dup-Thi- $1^{x}$ & North Carolina & 2006 & $\mathrm{~A} 2$ & $0.069 \pm 0.001$ & Tobacco \\
\hline Roc-Bak-14x & North Carolina & 2006 & A2 & $0.627 \pm 0.386$ & Tobacco \\
\hline Sam-Fai-6 $6^{x}$ & North Carolina & 2006 & A1 & $0.069 \pm 0.003$ & Tobacco \\
\hline Yad-Bro-14x & North Carolina & 2006 & A2 & $0.237 \pm 0.198$ & Tobacco \\
\hline $17 \mathrm{H} 1^{\mathrm{y}}$ & Virginia & 2001 & $\mathrm{~A} 2$ & $0.077 \pm 0.008$ & Forsythia \\
\hline $31 \mathrm{~A} 3^{\mathrm{y}}$ & Virginia & 2004 & $\mathrm{~A} 2$ & $>100$ & Petunia \\
\hline $28 \mathrm{~B}^{\mathrm{y}}$ & Virginia & 2002 & $\mathrm{~A} 2$ & $>100$ & Lavender \\
\hline $39 \mathrm{D} 4^{\mathrm{y}}$ & Virginia & 2006 & A1 & $0.040 \pm 0.007$ & Lavender \\
\hline $1 \mathrm{E} 3^{\mathrm{y}}$ & Virginia & 2000 & A1 & $0.045 \pm 0.007$ & Unknown ${ }^{2}$ \\
\hline $3 \mathrm{~A} 4^{\mathrm{y}}$ & Virginia & 2000 & $\mathrm{~A} 2$ & $>100$ & Unknown ${ }^{2}$ \\
\hline
\end{tabular}

" Effective mefenoxam concentration resulting in 50\% reduction of mycelial growth relative to the control treatment in which the isolates were not exposed to mefenoxam. Isolates were tested in duplicate at each fungicide concentration and the experiment was repeated. SD $=$ standard deviation.

${ }^{\mathrm{v}}$ From the collection of N. C. Gudmestad, North Dakota State University.

${ }^{\mathrm{w}}$ From the collection of R. P. Mulrooney, University of Delaware.

${ }^{x}$ From the collection of H. D. Shew, North Carolina State University.

${ }^{y}$ From the collection of C. Hong, Virginia Polytechnic Institute and State University.

${ }^{\mathrm{z}}$ Water was collected as effluent from a recycling irrigation system at a commercial container nursery producing a diverse range of perennial ornamental plant species. 
control treatment. Disks containing mycelium and agar were excised from the margin of an actively growing colony of a 3- to 5day-old culture of each isolate with a number 2 cork borer. A 5$\mathrm{mm}$-diameter disk of colonized agar was positioned in the center of $100 \mathrm{~mm}$ diameter $\times 15 \mathrm{~mm}$ deep, plastic petri dishes with the mycelium in contact with the agar medium. Testing consisted of two replications per mefenoxam concentration per isolate per trial. Plates were arranged in a randomized complete block design (RCBD) for each independent trial.

Isolate growth on mefenoxam-amended agar medium, as a measure of mefenoxam sensitivity, was assessed by measuring colony diameter in two perpendicular directions after 6 days of incubation in the dark at $20 \pm 1{ }^{\circ} \mathrm{C}$. Colony diameters were averaged for the two measurements from each replicate plate, the diameter of the mycelial plug was subtracted from this average, and relative growth reduction at each fungicide concentration was calculated as follows: $\{100-$ [(colony diameter on fungicideamended agar medium)/(colony diameter in the nonamended control plate) $\times 100\}$. The effective concentration $\left(\mathrm{EC}_{50}\right)$ resulting in $50 \%$ reduction of mycelial growth relative to the control plate was estimated for each isolate from the dose response curve. The latter was generated by plotting percent inhibition against the log-scale of fungicide concentration. $\mathrm{EC}_{50}$ values were determined from two independent sensitivity trials conducted for each isolate. Based upon results of previous work (42), isolates with $\mathrm{EC}_{50}$ values $<1.0$ $\mu \mathrm{g} / \mathrm{ml}$ were considered to be sensitive to mefenoxam, and isolates with $\mathrm{EC}_{50}$ values $>100 \mu \mathrm{g} / \mathrm{ml}$ were considered to be resistant to the fungicide.

Pathogenicity and aggressiveness of $P$. nicotianae isolates. Isolates of $P$. nicotianae used to evaluate pathogenicity and aggressiveness on potato were selected based on host source, geographic distribution, collection year, mating type, and mefenoxam sensitivity, in addition to traits determined for nine of the isolates in a previous characterization study (41). The 23 P. nicotianae isolates selected were collected in seven states from five host species or as naturally occurring isolates in irrigation water, from 1995 to 2008 (Table 2). Each isolate was grown on $10 \% \mathrm{CV} 8$ agar medium in an environmentally controlled chamber at $20 \pm 1{ }^{\circ} \mathrm{C}$ in the dark. After 3 days, 3-mm-diameter disks containing mycelium and agar were cut from colony margins with a number 1 cork borer and transferred to plastic culture plates (3 disks/plate) containing $10 \mathrm{ml}$ autoclaved $10 \% \mathrm{CV} 8$ juice broth $(100 \mathrm{ml} \mathrm{V} 8$ juice centrifuged at $3,000 \mathrm{rpm}$ for $20 \mathrm{~min}$ to remove pulp, and $900 \mathrm{ml}$ deionized water). The broth was removed from the plates with a sterile pipet after the liquid cultures were incubated for $72 \mathrm{~h}$ at $20 \pm 1^{\circ} \mathrm{C}$ in the dark. Mycelial mats were rinsed twice with $10 \mathrm{ml}$ sterile deionized water and resuspended in $10 \mathrm{ml}$ autoclaved soil extract water (10\%, prepared with $100 \mathrm{~g}$ soil from a potato field added to $900 \mathrm{ml}$ deionized water). Sporangia formed within 8 to $12 \mathrm{~h}$ under constant illumination, and abundant zoospores were released spontaneously within 24 to $36 \mathrm{~h}$. Zoospore concentration was determined using a hemacytometer and adjusted to $2.5 \times 10^{4}$ zoospores $/ \mathrm{ml}$ for inoculations. To facilitate counting zoospores, zoospore motility was moderated by chilling the hemacytometer slide at $10^{\circ} \mathrm{C}$ for approximately 2 min before counting. Zoospore suspensions were held at 20 to $25^{\circ} \mathrm{C}$ until inoculations were carried out, generally within 10 to $60 \mathrm{~min}$.

Tubers of Russet Norkotah (each 175 to 275 g) and Russet Burbank (each 150 to $250 \mathrm{~g}$ ), cultivars susceptible and moderately resistant to infection by $P$. erythroseptica $(33,43)$, respectively, were inoculated to assess pathogenicity and aggressiveness of each isolate of $P$. nicotianae. Tubers were removed from storage, inspected for damage or disease symptoms, and acclimated for 24 to $48 \mathrm{~h}$ at ambient temperature $\left(24\right.$ to $27^{\circ} \mathrm{C}$ ). Disease-free tubers with apical eyes free of soil and an intact periderm were placed in 33 $\mathrm{cm}$ long $\times 24 \mathrm{~cm}$ wide $\times 12 \mathrm{~cm}$ deep plastic moist chamber boxes lined with paper towels moistened with deionized water. Each tuber was inoculated at each of three apical eyes with $10 \mu \mathrm{l}$ zoospore suspension (approximately 250 zoospores/inoculation site). Inoculated tubers were covered with four layers of paper towels moistened to saturation with deionized water. Chamber boxes were covered to establish high humidity to promote infection and incubated in the dark at an ambient temperature of 24 to $27^{\circ} \mathrm{C}$ for 7 days. Evaluations were conducted as two separate trials, each consisting of four replications of five tubers for a total of 40 tubers/cultivar/isolate. Plastic boxes containing inoculated tubers were arranged in a RCBD. The quantity of tubers available of the desired size and condition was limited; therefore, a water-inoculated control treatment for each cultivar was not included.

Susceptibility of potato cultivars to $P$. nicotianae. Potato germplasm used in this study included 8 red-skinned cultivars, 9 white-skinned cultivars, and 10 russet cultivars (Table 3 ). This material was selected to represent a broad spectrum of genetic backgrounds including a combination of established cultivars as well as recently released cultivars. Certified seed of the 26 potato cultivars was obtained from seed potato producers in North Dakota and Minnesota, and seed of Dakota Trailblazer was provided by the breeding program at North Dakota State University (courtesy of A. Thompson). Field plots were established at a nonirrigated location near Grand Forks, ND on 2 June 2008, and under overhead irrigation near Inkster, ND on 1 June 2009. Whole and cut seed tubers were planted at a $0.3-\mathrm{m}$ in-row spacing in paired, $35 \mathrm{~m}$ long rows with rows spaced $0.9 \mathrm{~m}$ apart. Agronomic practices commonly used in commercial potato production in North Dakota were implemented throughout the growing season. Following harvest, tubers were inspected for damage, pink rot, and other disease symptoms, then placed into storage where they were held for 2 weeks at $15^{\circ} \mathrm{C}$ and $90 \%$ relative humidity to promote wound healing. Tubers subsequently were stored at $10^{\circ} \mathrm{C}$ until inoculation studies were conducted. Cultivar susceptibility was assessed following procedures similar to those used in previous studies evaluating susceptibility of potato germplasm to infection by $P$. erythroseptica $(33,43,46)$ and $P$. nicotianae $(41)$, using isolate 06TX1-3. This isolate had previously been characterized extensively and used in inoculation studies (41). Cultivar susceptibility evaluations were carried out as two separate trials each year, each trial consisting of four replications of 10 tubers/cultivar for a total of 80 tubers/cultivar screened each year.

Disease assessment. Disease development in both the pathogenicity and aggressiveness trials as well as the cultivar susceptibility trials was quantified using techniques similar to those described in previous studies $(33,41-44,46)$. Nonwounded tubers were removed from moist chambers and cut in half through the axis of the sites of inoculation, from the apical buds to the basal stem end. Split tubers were covered with paper towels moistened with deionized water and incubated at 20 to $24^{\circ} \mathrm{C}$ for approximately $30 \mathrm{~min}$ to enhance development of tan to pale brown discoloration diagnostic of $P$. nicotianae infection. Infected tubers were counted, and disease incidence (I) was calculated as: (number of diseased tubers $) /($ number of inoculated tubers $) \times 100$. Disease severity was estimated by measuring the maximum depth (D) of rotted tissue from the point of inoculation, and a penetration rate $(\mathrm{P})$ was calculated as: $\mathrm{P}=\mathrm{D} / \mathrm{T}$, where $\mathrm{T}=$ time (days) after inoculation.

Cultivar susceptibility also may be characterized by quantifying disease severity as the rate of tissue penetration following infection $(43,46)$. A plot of disease incidence versus rate of tuber penetration was used to evaluate and categorize aggressiveness of the $P$. nicotianae isolates on potato tubers and susceptibility of the potato cultivars to tuber infection by $P$. nicotianae. Those isolates nearest the $\mathrm{x}-\mathrm{y}$ origin displayed the lowest incidence and slowest rate of tuber penetration and, therefore, were determined to be the least aggressive on potato tubers. Similarly, those potato cultivars nearest the $\mathrm{x}-\mathrm{y}$ origin displayed the lowest incidence and slowest rate of tuber penetration and, therefore, were determined to be the most resistant to tuber infection. These categorizations have been used in previous work with $P$. erythroseptica $(33,42-44,46)$ based upon results of inoculation studies and field observations of cultivar susceptibility.

Data analyses. Levene's test for homogeneity of variance was conducted for all tuber inoculation trials. The effects of trial, as 
well as trial interactions with other main effects, were included in the analyses of variance (ANOVAs) to test if data could be combined for further analysis $(\alpha=0.05)$ (20). A factorial ANOVA was performed on disease incidence (\% infection) data from the isolate pathogenicity and aggressiveness trials. Trial, cultivar (Russet Burbank and Russet Norkotah), and pathogen isolate were analyzed as fixed main effects. Means were separated using Fishers protected least significant difference (LSD) test $(\alpha=0.05)$. Pearson's correlation coefficient was calculated for disease incidence (\% infection) data derived from $P$. nicotianae isolate pathogenicity and aggressiveness trials to compare pink rot development in Russet Norkotah and Russet Burbank. For comparisons across types of cultivars and within each type of cultivar (red, white, or russet), a two-stage nested ANOVA was calculated with PROC GLIMMIX using potato type and cultivar nested within type as the factors for each year (trial). Type I error in these pair-wise comparisons was controlled using the Tukey adjustment (35).

\section{Results}

P. nicotianae distribution. P. nicotianae infections of potato were verified in Nebraska, Michigan, Missouri, and Texas (Table 1). Seventy-seven isolates were collected from six locations in these states. Of these, 32 isolates were recovered from leaves, 7 from petioles, 24 from stems, and 14 from tubers across all locations and years. P. erythroseptica was not recovered from any infected potato samples at these sites. All isolates collected in 2008, 2009, and 2010 were sensitive to mefenoxam, with mean $\mathrm{EC}_{50}$ values ranging from 0.03 to $0.10 \mu \mathrm{g} / \mathrm{ml}$ (Table 1).

Isolate characterization. $P$. nicotianae isolate identity was confirmed by morphological characteristics and species-specific DNA amplification by PCR assay and sequencing. Colony morphology was very similar among isolates, with all isolates fitting the range in colony morphology described for the species (6). All isolates had hyphae with slight to prominent hyphal swellings, and produced a rosette to arachnoid colony type (6). All isolates produced sporangia and chlamydospores, and some isolates produced zoo- spores in the agar medium. Sporangia were variable in size and shape, but most were ellipsoid, ovoid, obpyriform, or spherical, and all had the prominent papilla typical of $P$. nicotianae. Chlamydospores typical of $P$. nicotianae were produced by all isolates.

$P$. nicotianae species-specific primers amplified DNA of the positive control isolate but not the negative control isolate. Of the 77 isolates identified as $P$. nicotianae based on morphological features characteristic for the species, only 68 had DNA amplified by the PCR assay, despite repeated efforts with the probe. Internal transcribed spacer (ITS) sequencing was completed for the 68 isolates that were amplified, and the sequences were Blasted against the available sequences of GenBank accessions through NCBI Blast. All 68 isolates were identified as P. nicotianae based on $>99 \%$ similarity to the reported ITS sequences of $P$. nicotianae isolates. Mating-type pairings indicated that all but two of the potato isolates collected in 2008 to 2010 were the A2 mating type, with one A1 isolate collected from a potato leaf in Nebraska and one from a potato petiole in Texas (Table 1). Isolates of both mating types were used in the pathogenicity and aggressiveness trials.

Twenty of $23 P$. nicotianae isolates used in the aggressiveness and cultivar susceptibility trials were sensitive to mefenoxam (Table 2), with $\mathrm{EC}_{50}$ values ranging from 0.04 to $0.63 \mu \mathrm{g} / \mathrm{ml}$. However, petunia isolate 31A3 from Virginia, lavender isolate 28B5 from Virginia, and isolate 3A4 collected from irrigation water in Virginia were resistant to the fungicide $\left(\mathrm{EC}_{50}>100 \mu \mathrm{g} / \mathrm{ml}\right)$. The isolates represented a diversity of mating types. Nine of the 12 potato isolates selected for this study were characterized previously (41). With the exception of 06NE1-5 (A1) and 07MO1-1 (A0), the remaining 10 isolates from potato were of the A2 mating type. Of the isolates from other hosts or irrigation water (hosts unknown), 8 were mating type $\mathrm{A} 2$ and 3 were mating type A1.

Isolate pathogenicity and aggressiveness. Variances across the two pathogenicity and aggressiveness trials for the isolates of $P$. nicotianae were homogeneous based on Levene's test $(P=$ 0.7642); however, a significant trial-by-isolate interaction was observed $(P<0.0001)$. Inoculations of Russet Norkotah tubers

Table 3. Potato cultivars evaluated for susceptibility to tuber rot caused by Phytophthora nicotianae

\begin{tabular}{|c|c|c|c|}
\hline Cultivar & Parentage $^{y}$ & Release year $^{\mathrm{z}}$ & Maturity rating $^{y}$ \\
\hline \multicolumn{4}{|l|}{ Red cultivars } \\
\hline Dakota Jewel & ND2223-8R × ND649-4R & 2004 & Medium-late \\
\hline Dakota Rose & ND1196-2R × NorDonna & 2000 & Early-medium \\
\hline Dark Red Norland & Mutant of Red Norland & $1989(1965)$ & Early \\
\hline Red LaSoda & Mutant of La Soda (Triumph $\times$ Katahdin) & $1953(1948)$ & Main-season \\
\hline Red Norland & Clone from Norland (Redkote $\times$ ND626) & 1965 (1957) & Early \\
\hline Red Pontiac & Triumph $\times$ Katahdin & 1945 & Late \\
\hline Sangre & Viking $\times$ A6356-9 & 1982 & Medium \\
\hline Viking & Nordak $\times$ Redskin & 1963 & Main-season \\
\hline \multicolumn{4}{|l|}{ Russet cultivars } \\
\hline Alturas & A77182-1 × A75188-3 & 2002 & Late \\
\hline Bannock Russet & A75175-1 × A75188-3 & 1999 & Late \\
\hline Dakota Trailblazer & A89163-3LS × A8914-4 & 2010 & Full season \\
\hline Goldrush & ND450-3Russ $\times$ Lemhi Russet & 1992 & Medium \\
\hline Premier Russet & A $87149-4 \times$ A88108-7 & 2006 & Medium-late \\
\hline Ranger Russet & Butte $\times$ A6595-3 & 1991 & Full season \\
\hline Russet Norkotah & ND9526-4 Russ $\times$ ND9687-5 Russ & 1987 & Early-medium \\
\hline Russet Burbank & Chimera of Burbank (Early Rose × ?) & 1914 (1876) & Late \\
\hline Silverton Russet & CalWhite $\times$ A7875-5 & 1999 & Medium \\
\hline Umatilla Russet & Butte $\times$ A77268-4 & 1998 & Medium-late \\
\hline \multicolumn{4}{|l|}{ White cultivars } \\
\hline Atlantic & Wauseon $\times$ USDA B5141-6 (Lenape) & 1976 & Medium \\
\hline Dakota Crisp & Yankee Chipper $\times$ Norchip & 2005 & Medium \\
\hline Dakota Diamond & ND4103-2 $\times$ Dakota Pearl & 2005 & Medium-late \\
\hline Dakota Pearl & ND1118-1 and ND944-6 & 1999 & Medium \\
\hline Kennebec & B127 × USDA 96-56 & 1948 & Medium \\
\hline Norvalley & ND860-2 × Norchip & 1997 & Medium \\
\hline Shepody & Bake-King $\times$ F58050 & 1980 & Medium-late \\
\hline Snowden & B5141-6 (Lenape) $\times$ Wischip & 1990 & Full-season \\
\hline Yukon Gold & W5279-4 × Norgleam & 1980 & Medium \\
\hline
\end{tabular}

${ }^{\text {y }}$ From online resources: http://potatoassociation.org/index.html; http://www.plantbreeding.wur.nl/potatopedigree/.

${ }^{z}$ Date denotes year the cultivar was released. Date in parentheses denotes release year of original cultivar from which the variant genotype was derived. 
resulted in mean infection rates greater than two times that observed on Russet Burbank tubers and, therefore, a significant difference in infection incidence between cultivars $(P<0.0001)$ (Table 4). No significant interaction between the main effects of trial and P. nicotianae isolate was observed for Russet Burbank (data not shown). However, a significant interaction was detected between the main effects of trial and isolate for Russet Norkotah. This interaction resulted from isolates which caused very low tuber infection incidences and, therefore, very low variances. Therefore, infection incidence data were combined across trials within each cultivar. Significant differences in incidence of tubers infected were observed among isolates for both Russet Norkotah $(P<$ $0.0001)$ and Russet Burbank $(P<0.0001)$ tubers (Table 4$)$.

In general, isolates recovered from potato caused greater infection incidences on both cultivars compared to most isolates originating from nonpotato hosts or from irrigation water (unknown original host). Although a significant interaction between cultivar and isolate $(P<0.0001)$ was observed, this interaction was due to the magnitude of decrease in infection incidence on Russet Norkotah tubers (susceptible) versus Russet Burbank tubers (moderately resistant). Overall, all isolates of $P$. nicotianae infected tubers of cv. Russet Norkotah at a higher frequency than tubers of Russet Burbank, except when infection incidences were relatively low, as for isolates 28B5 (lavender), Yad-Bro-14 (tobacco), and $31 \mathrm{~A} 3$ (petunia). Isolate Roc-Bak-14 from tobacco did not cause tuber infections on either cultivar (Table 4). Overall, a strong and significant correlation ( $r=0.8979 ; P<0.0001 ; n=23)$ between

Table 4. Infection incidence of zoospores of Phytophthora nicotianae isolates collected from various hosts and inoculated onto nonwounded tubers of potato cvs. Russet Norkotah and Russet Burbank

\begin{tabular}{|c|c|c|c|}
\hline \multirow[b]{2}{*}{ Isolate } & \multirow[b]{2}{*}{$\begin{array}{l}\text { Host } \\
\text { (source tissue) }\end{array}$} & \multicolumn{2}{|c|}{ Infection incidence $(\%)^{\mathrm{u}}$} \\
\hline & & $\begin{array}{c}\text { Russet } \\
\text { Norkotah }\end{array}$ & $\begin{array}{c}\text { Russet } \\
\text { Burbank }\end{array}$ \\
\hline$N 3^{\mathrm{v}}$ & Potato (tuber) & $90.0 \mathrm{a}$ & $62.5 \mathrm{a}$ \\
\hline $08 \mathrm{MO} 1-2^{\mathrm{w}}$ & Potato (leaf) & $90.0 \mathrm{a}$ & $50.0 \mathrm{ab}$ \\
\hline $08 \mathrm{TX} 2-1^{\mathrm{w}}$ & Potato (tuber) & $90.0 \mathrm{a}$ & $47.5 \mathrm{ab}$ \\
\hline $08 \mathrm{TX1} 1-9^{\mathrm{w}}$ & Potato (leaf) & $90.0 \mathrm{a}$ & $37.5 \mathrm{bcd}$ \\
\hline $07 \mathrm{TX} 1-1^{\mathrm{w}}$ & Potato (leaf) & $87.5 \mathrm{ab}$ & $42.5 \mathrm{cb}$ \\
\hline $07 \mathrm{MO} 1-3^{\mathrm{w}}$ & Potato (tuber) & $85.0 \mathrm{ab}$ & $50.0 \mathrm{ab}$ \\
\hline $06 \mathrm{FL} 1-7^{\mathrm{w}}$ & Potato (tuber) & $85.0 \mathrm{ab}$ & $42.5 \mathrm{bc}$ \\
\hline $07 \mathrm{TX} 2-1^{\mathrm{w}}$ & Potato (petiole) & $80.0 \mathrm{abc}$ & $45.0 \mathrm{bc}$ \\
\hline $05 N E 1-1^{w}$ & Potato (tuber) & 77.5 abcd & $37.5 \mathrm{bcd}$ \\
\hline $06 \mathrm{TX} 1-3^{\mathrm{w}}$ & Potato (leaf) & $77.5 \mathrm{abcd}$ & 35.0 bcde \\
\hline $1 \mathrm{E} 3^{\mathrm{x}}$ & Unknown ${ }^{y}$ & $75.0 \mathrm{bcd}$ & $30.0 \mathrm{cdef}$ \\
\hline $06 \mathrm{NE} 1-5^{\mathrm{w}}$ & Potato (leaf) & 70.0 cde & 25.0 defg \\
\hline $07 \mathrm{MO} 1-1^{\mathrm{w}}$ & Potato (tuber) & $65.0 \mathrm{de}$ & 17.5 fghi \\
\hline $39 \mathrm{D} 4^{\mathrm{x}}$ & Lavender & $60.0 \mathrm{e}$ & $5.0 \mathrm{hij}$ \\
\hline $3 \mathrm{~A} 4^{\mathrm{x}}$ & Unknown ${ }^{y}$ & $45.0 \mathrm{f}$ & 12.5 ghij \\
\hline Dup-Thi- $1^{z}$ & Tobacco & $32.5 \mathrm{fg}$ & $5.0 \mathrm{hij}$ \\
\hline $28 B 5^{x}$ & Lavender & $22.5 \mathrm{gh}$ & $20.0 \mathrm{efgh}$ \\
\hline Dav-Whi-7z & Tobacco & $15.0 \mathrm{hi}$ & $2.5 \mathrm{ij}$ \\
\hline $17 \mathrm{H} 1^{x}$ & Forsythia & 12.5 hij & $5.0 \mathrm{hij}$ \\
\hline Sam-Fai-6 ${ }^{z}$ & Tobacco & $10.0 \mathrm{hij}$ & $0.0 \mathrm{j}$ \\
\hline Yad-Bro-14 & Tobacco & $2.5 \mathrm{ij}$ & $2.5 \mathrm{ij}$ \\
\hline $31 \mathrm{~A} 3^{\mathrm{x}}$ & Petunia & $2.5 \mathrm{ij}$ & $2.5 \mathrm{ij}$ \\
\hline Roc-Bak-14z & Tobacco & $0.0 \mathrm{j}$ & $0.0 \mathrm{j}$ \\
\hline Mean & & $55.0 \mathrm{~A}$ & $25.1 \mathrm{~B}$ \\
\hline$P$ value & & $<0.0001$ & $<0.0001$ \\
\hline
\end{tabular}

"Values followed by the same lowercase (column) or uppercase (row) letter are not statistically different based on Fisher's protected least significant difference $(\alpha=0.05)$. The interaction of the main effects of cultivar and isolate was signifant $(P<0.0001)$. Evaluations were conducted as two separate trials, each consisting of four replications of five tubers for a total of 40 tubers/cultivar/isolate.

${ }^{\vee}$ From the collection of R. P. Mulrooney, University of Delaware.

${ }^{\text {w }}$ From the collection of N. C. Gudmestad, North Dakota State University.

${ }^{x}$ From the collection of C. Hong, Virginia Polytechnic Institute and State University.

${ }^{\mathrm{y}}$ Water was collected as effluent from a recycling irrigation system at a commercial container nursery producing a diverse range of perennial ornamental plant species.

${ }^{\mathrm{z}}$ From the collection of H. D. Shew, North Carolina State University. disease incidence on Russet Norkotah versus Russet Burbank tubers existed across all $P$. nicotianae isolates (Fig. 1).

Tuber infection incidences for the potato isolates of $P$. nicotianae were not correlated significantly with the potato plant tissue of origin. Isolates $\mathrm{N} 3$ from tuber tissue and 08MO1-2 from leaf tissue resulted in the highest infection incidences on both cultivars, while inoculations with isolate 06NE1-5 obtained from a potato leaf and isolate 07MO1-1 from a tuber resulted in the lowest incidences of infection on both Russet Norkotah and Russet Burbank tubers (Table 4). Based upon infection incidence, the overall ranking of the potato isolates was consistent across both cultivars. Greater variation was observed in the rankings of isolates recovered from other host species and irrigation water than among the potato isolates. With the exception of isolates Roc-Bak-14 and Sam-Fai-6 recovered from tobacco, zoospores of all these other isolates were able to infect tubers of both Russet Norkotah and Russet Burbank following inoculation through the apical eyes (Table 4). Nearly all $(83 \%)$ of the potato isolates were highly aggressive when inoculated onto tubers of Russet Norkotah and Russet Burbank (Table 4, Fig. 2). All of these isolates were of the A2 mating type. Potato isolates 06NE1-5 (A1) and 07MO1-1 (A0) exhibited moderately low aggressiveness on these cultivars. Isolate 1E3, collected from irrigation water (unknown original host), also was highly aggressive on potato tubers (Table 4, Fig. 2). Isolates 39D4 (lavender) and 3A4 (irrigation water) demonstrated moderately low aggressiveness, whereas the remaining isolates obtained from nonpotato plant hosts displayed low aggressiveness on potato (Fig. 2, Table 4).

Cultivar susceptibility. Infected tissue of potato tubers inoculated with $P$. nicotianae isolate 06TX1-3 had a spongy, rubbery, watery consistency, and the flesh color varied with cultivar from pale tan to dark pinkish brown, which is typical of $P$. nicotianae infections $(4,12,41)$. No significant main effect of trial or significant interaction of trial with other main effects was observed for the incidence of tubers infected in 2008, when the tubers used for this experiment were produced under nonirrigated conditions (Table 5). However, in 2009, while the main effect of trial was not significant, there was a significant interaction of trial with cultivar type due to inconsistent results for two white cultivars, Dakota Crisp and Shepody. Because data were consistent for the other cultivars, and variances were homogeneous $(P=0.2832)$, data

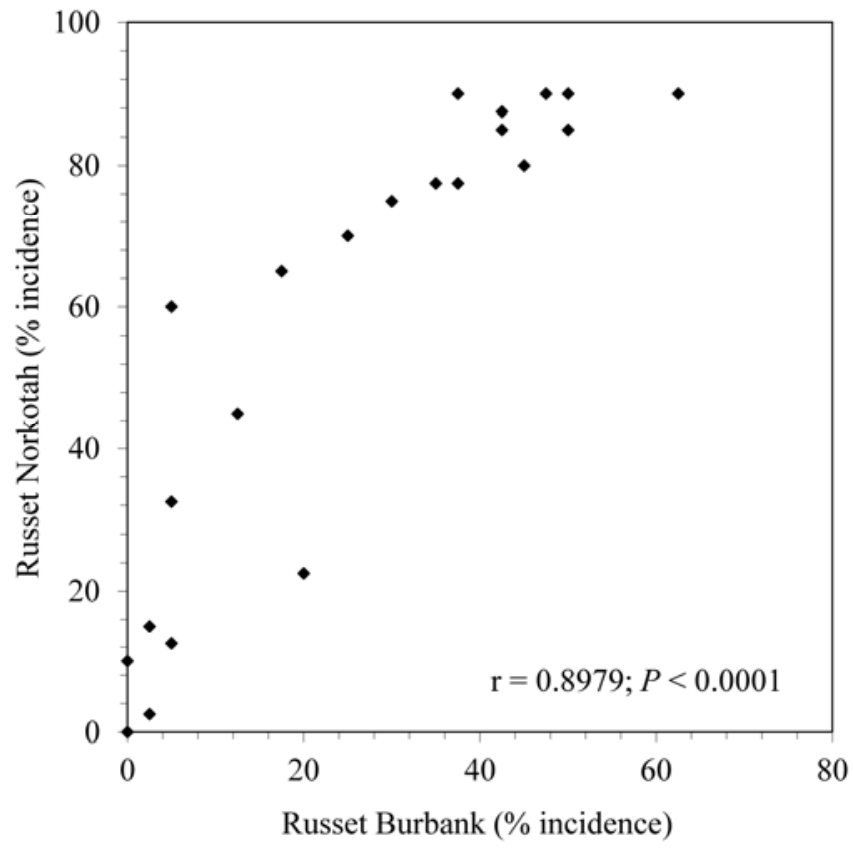

Fig. 1. Pearson's correlation coefficient comparing incidence (\%) of tubers of potato cvs. Russet Burbank and Russet Norkotah with symptoms of tuber rot following inoculation with 23 isolates of Phytophthora nicotianae. 
from the two trials within each year were combined for further analysis (Tables 5 and 6).

In 2008, when tubers were produced under nonirrigated conditions, significant differences in disease incidence were observed across all cultivars, and infection incidences ranged from $31.3 \%$ for Umatilla Russet tubers to $100 \%$ in Red Norland tubers (Table 5). A significant difference also was observed within all three phenotypic groups or types of cultivars (red, russet, and white types). Red cultivars as a whole were significantly more susceptible to $P$. nicotianae when compared to russet and white cultivars, while russet cultivars were least susceptible (Table 5). Pairwise comparisons obtained in the nested analyses indicated that significant differences were present within each cultivar type in the 2008 trials. Of the eight red cultivars, seven were statistically similar and highly susceptible. Red Pontiac had the lowest incidence of infection among the red cultivars. Six of the white cultivars were significantly more susceptible to tuber infection, with the greatest mean incidence of infection observed on Snowden and Yukon Gold tubers; while Shepody, Dakota Crisp, and Atlantic were the least susceptible of the white cultivars. Five of the 10 russet cultivars had the highest tuber incidence ratings statistically, including Gold Rush, Russet Norkotah, Alturas, Bannock Russet, and Silverton Russet. Umatilla Russet and Ranger Russet had the least number of tubers infected (although not significantly different than that of Russet Burbank, Premier Russet, and Dakota Trailblazer).

In 2009, significant differences in the incidence of infected tubers also was observed for the same potato cultivars produced under irrigation (Table 6). Across all cultivars, tuber infection inci-

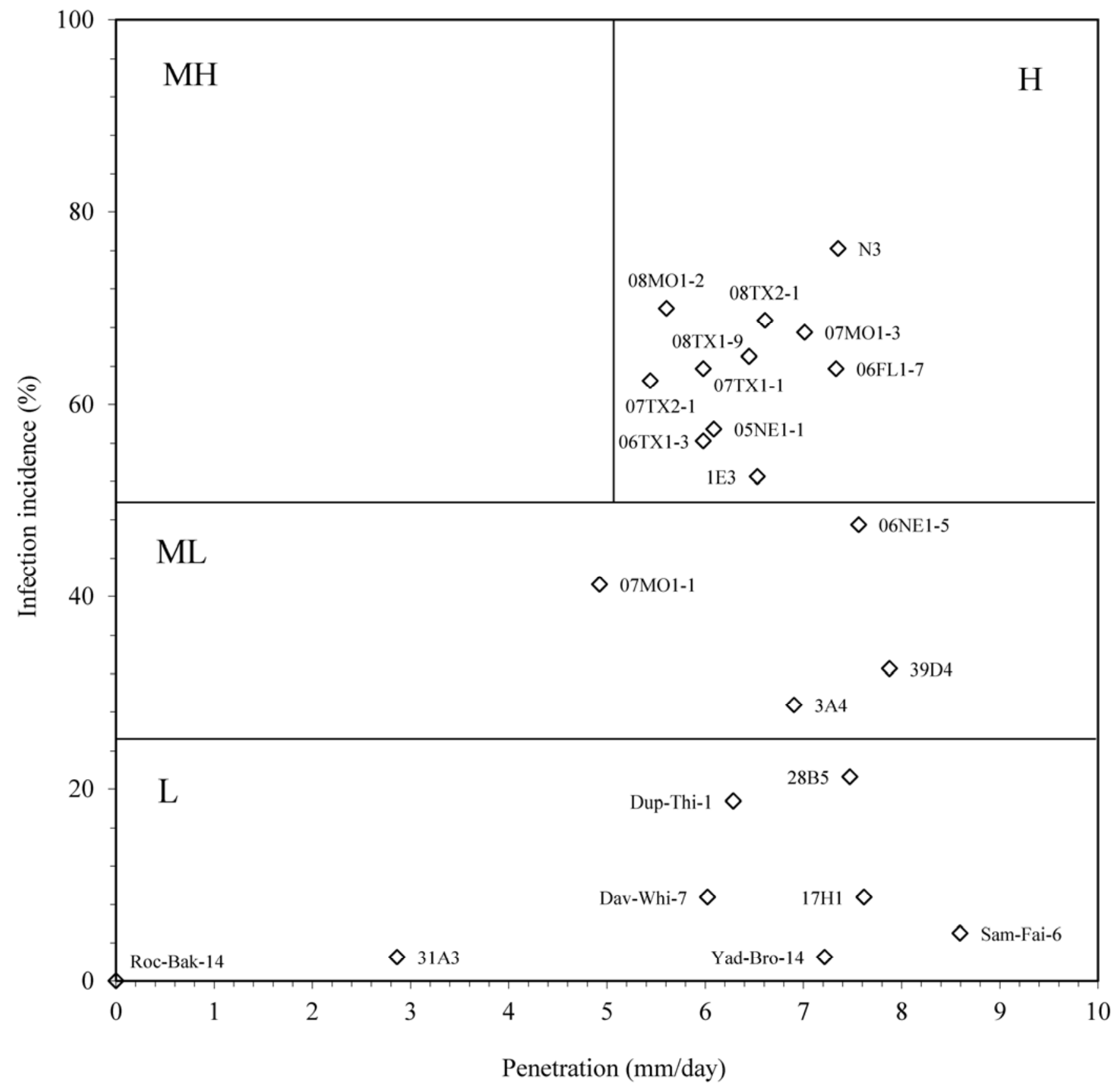

Fig. 2. Relative aggressiveness of 23 Phytophthora nicotianae isolates inoculated postharvest onto tubers of potato cvs. Russet Burbank and Russet Norkotah, based on paired values of incidence of tubers infected (susceptibility to tuber infection, shown on the $y$-axis) and rate of tuber penetration (mm/day as a measure of susceptibility of the tuber to colonization, shown on the $x$-axis). Symbols closer to the origin of the $x$-y axes denote less disease. Graph is divided to denote postulated host-pathogen interactions representing varying levels of isolate aggressiveness: high $(\mathrm{H})$, moderately high $(\mathrm{MH})$, moderately low $(\mathrm{ML})$, and low $(\mathrm{L})$. Separation of $L$ and $M L$ categories is based on infection incidence only. Separation of $\mathrm{MH}$ and $\mathrm{H}$ categories of infection is based on the rate of pathogen penetration into potato tubers. Refer to Table 2 for details of $P$. nicotianae isolates. Each data point is the mean of four replications in each of two trials. 
dence was lower in 2009 than in 2008. In 2009, Umatilla Russet tubers again displayed the lowest incidence (7.5\% tubers infected), although this was not significantly different than the incidence of tubers infected for 16 other cultivars. Tubers of Yukon Gold displayed the greatest disease incidence $(76.3 \%)$, which was not significantly different than the incidence observed on tubers of nine other cultivars evaluated. As a whole, infections incidences in tubers of white and red cultivars were not significantly different. Infection incidences in russet cultivars did differ significantly from those of white cultivars but not red cultivars (Table 6). Pairwise comparisons in the nested analyses indicated that significant differences were present among russet cultivars and among white cultivars, but not among red cultivars. As in 2008, Gold Rush and Russet Norkotah had the greatest incidence of tubers infected among russet cultivars, although not significantly different from that of six other russet cultivars based on the LSD means comparison; and Umatilla Russet and Ranger Russet had the lowest incidence of tubers infected among the russet cultivars (although not significantly different from that of four other russet cultivars). Among white tuber cultivar types, Yukon Gold, NorValley, and Snowden had the greatest infection incidence, and Atlantic the least tubers infected in 2009 (later not significantly different from the tuber infection incidence of six other white cultivars).

Although considerable variation in tuber penetration rates by $P$. nicotianae was observed across all cultivars, the mean disease severity of each group was similar (red cultivars $=5.6$, russet cultivars $=6.0$, and white cultivars $=5.7 \mathrm{~mm} /$ day) (Fig. 3). Based upon the combination of tuber infection incidence and rate of tuber penetration, Yukon Gold was the cultivar most susceptible to infection by $P$. nicotianae in this study, whereas Ranger Russet and

Table 5. Incidence of infection of Phytophthora nicotianae isolate 06TX13 zoospores on nonwounded tubers of potato genotypes grown under nonirrigated conditions in 2008 in North Dakota

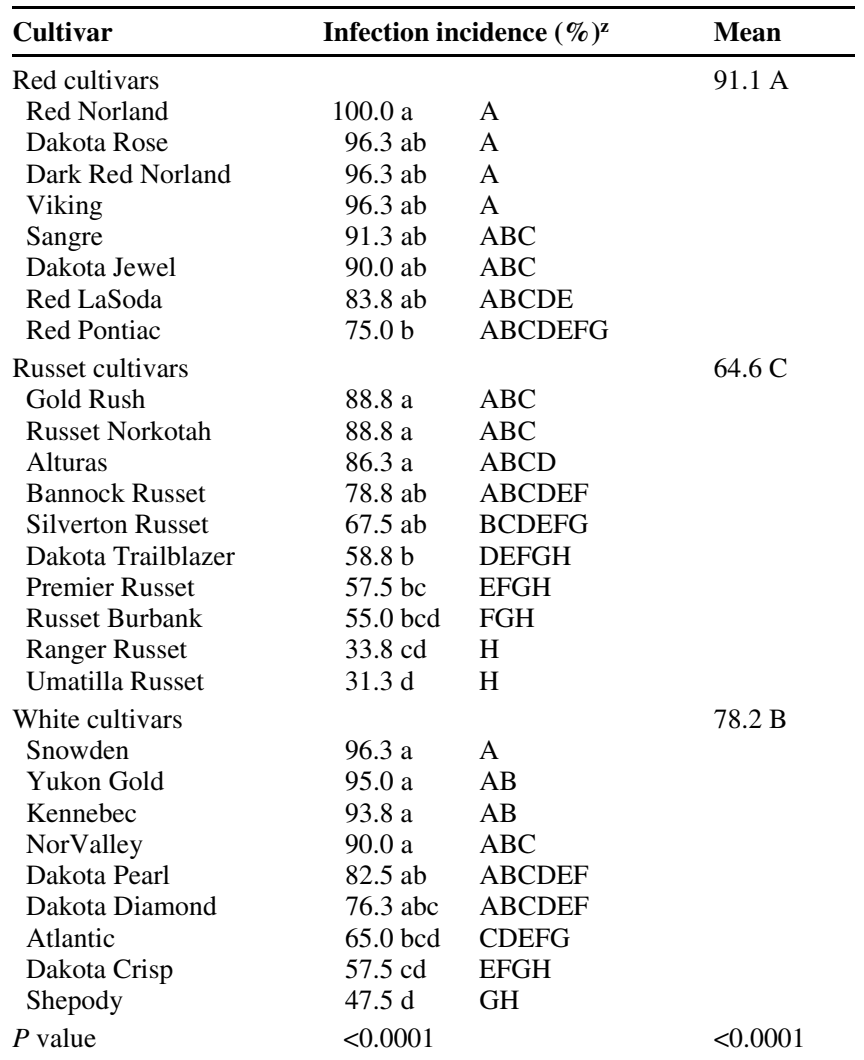

${ }^{z}$ Within each phenotypic group of cultivars, means followed by the same lowercase letter are not significantly different based on pairwise comparisons using Tukey's adjustment $(\alpha=0.05)$. Among all 27 potato cultivars, and within each phenotypic group, means followed by the same uppercase letter are not significantly different.
Umatilla Russet were the most resistant. Russet cultivars Dakota Trailblazer, Premier Russet, and Russet Burbank exhibited moderate levels of resistance to $P$. nicotianae, as did the white cultivars Atlantic, Dakota Crisp, and Shepody (Fig. 3).

\section{Discussion}

Research involving $P$. nicotianae infection of potato has been intermittent, and the current understanding of host-pathogen interactions primarily is based upon distributional surveys and characterization of a small group of pathogen isolates and potato cultivars $(12,22,26,41)$. This study represents a more comprehensive assessment of potato genotype susceptibility to isolates of $P$. nicotianae, as well as pathogenicity and aggressiveness of isolates from a broad sampling of the pathogen population within four states in the United States. Previous reports have documented tuber infections caused by $P$. nicotianae isolates from potato $(6,12,22,41)$; however, information regarding pathogenicity of isolates recovered from other host species has been scarce. In previous inoculation studies, isolates recovered from tomato failed to infect potato $(3,31)$. However in a subsequent study, infections were observed on excised potato leaves, whole potato plants, and tubers by zoospores and mycelia of $P$. nicotianae isolates recovered from tomato and tobacco (26). Results reported in this study confirm the pathogenicity of tobacco isolates on potato, and demonstrate that zoospores of $P$. nicotianae isolates from lavender, forsythia, and petunia are capable of infecting potato tubers, albeit at a much lower frequency than isolates recovered from potato. Zoospores of all 12 P. nicotianae isolates in this study that were recovered from potato were able to infect potato tubers through eyes. Ten of these isolates were highly aggressive and two demonstrated moderate to low aggressiveness. The highly aggressive isolates all

Table 6. Incidence of infection of Phytophthora nicotianae isolate 06TX13 zoospores on nonwounded tubers of potato genotypes grown under irrigated conditions in 2009 in North Dakota

\begin{tabular}{|c|c|c|c|}
\hline$\overline{\text { Cultivar }}$ & Infection & cidence $(\%)^{\mathrm{z}}$ & Mean \\
\hline $\begin{array}{l}\text { Red cultivars } \\
\text { Dakota Rose } \\
\text { Red Norland } \\
\text { Sangre } \\
\text { Dakota Jewel } \\
\text { Dark Red Norland } \\
\text { Red LaSoda } \\
\text { Red Pontiac } \\
\text { Viking }\end{array}$ & $\begin{array}{l}48.8 \mathrm{a} \\
43.8 \mathrm{a} \\
43.8 \mathrm{a} \\
40.0 \mathrm{a} \\
33.8 \mathrm{a} \\
27.5 \mathrm{a} \\
26.3 \mathrm{a} \\
25.0 \mathrm{a}\end{array}$ & $\begin{array}{l}\mathrm{ABC} \\
\mathrm{ABC} \\
\mathrm{ABC} \\
\mathrm{BCD} \\
\mathrm{BCD} \\
\mathrm{BCD} \\
\mathrm{BCD} \\
\mathrm{BCD}\end{array}$ & $36.1 \mathrm{AB}$ \\
\hline $\begin{array}{l}\text { Russet cultivars } \\
\text { Gold Rush } \\
\text { Russet Norkotah } \\
\text { Bannock Russet } \\
\text { Silverton Russet } \\
\text { Premier Russet } \\
\text { Alturas } \\
\text { Russet Burbank } \\
\text { Dakota Trailblazer } \\
\text { Ranger Russet } \\
\text { Umatilla Russet }\end{array}$ & $\begin{array}{l}53.8 \mathrm{a} \\
51.3 \mathrm{ab} \\
50.0 \mathrm{ab} \\
47.5 \mathrm{abc} \\
35.0 \mathrm{abcd} \\
23.8 \mathrm{bcd} \\
20.0 \mathrm{~cd} \\
17.5 \mathrm{~d} \\
8.8 \mathrm{~d} \\
7.5 \mathrm{~d}\end{array}$ & $\begin{array}{l}\text { AB } \\
\text { ABC } \\
\text { ABC } \\
\text { ABC } \\
\text { BCD } \\
\text { BCD } \\
\text { BCD } \\
\text { CD } \\
\text { D } \\
\text { D }\end{array}$ & $31.5 \mathrm{~B}$ \\
\hline $\begin{array}{l}\text { White cultivars } \\
\text { Yukon Gold } \\
\text { NorValley } \\
\text { Snowden } \\
\text { Dakota Pearl } \\
\text { Shepody } \\
\text { Dakota Diamond } \\
\text { Dakota Crisp } \\
\text { Kennebec } \\
\text { Atlantic }\end{array}$ & $\begin{array}{l}76.3 \mathrm{a} \\
52.5 \mathrm{ab} \\
48.8 \mathrm{ab} \\
40.0 \mathrm{bc} \\
38.8 \mathrm{bc} \\
32.5 \mathrm{bc} \\
25.0 \mathrm{bc} \\
23.8 \mathrm{bc} \\
17.5 \mathrm{c}\end{array}$ & $\begin{array}{l}\text { A } \\
\text { AB } \\
\text { ABC } \\
\text { BCD } \\
\text { BCD } \\
\text { BCD } \\
\text { BCD } \\
\text { BCD } \\
\text { CD }\end{array}$ & $39.4 \mathrm{~A}$ \\
\hline$P$ value & $<0.0001$ & & $<0.0001$ \\
\hline
\end{tabular}

${ }^{z}$ Within each phenotypic group of cultivars, means followed by the same lowercase letter are not significantly different based on pairwise comparisons using Tukey's adjustment $(\alpha=0.05)$. Among all 27 potato cultivars, and within each phenotypic group, means followed by the same uppercase letter are not significantly different. 
were of the A2 mating type; however, the isolates exhibiting moderately low aggressiveness were $\mathrm{A} 0$ and $\mathrm{A} 1$. This difference in aggressiveness could partially explain the preponderance of the A2 mating type recovered from potato infections.
Of the nine isolates of $P$. nicotianae from nonpotato hosts evaluated in this study, and two isolates obtained from irrigation water (unknown original host plants), only a single isolate from tobacco was nonpathogenic on tubers of potato cvs. Russet Norkotah and
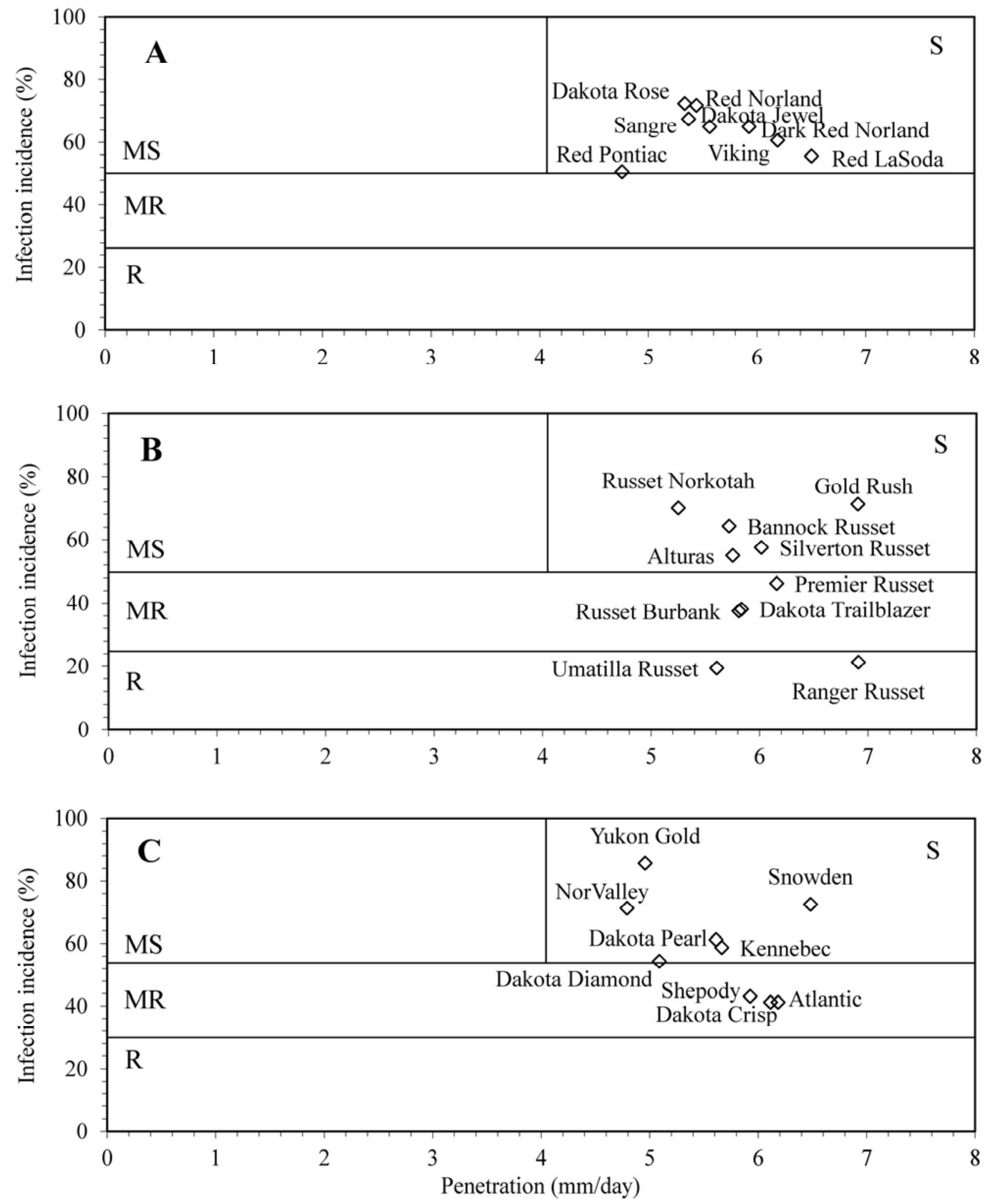

Fig. 3. Relative susceptibilities of A, red, B, russet, and C, white potato cultivars to infection by 23 isolates of Phytophthora nicotianae based on paired values of incidence of tubers infected (susceptibility to infection, shown on the $y$-axis) and rate of tuber penetration by the isolate (mm/day as a measure of susceptibility to colonization, shown on the x-axis). Symbols closer to the origin of the $x-y$ axes denote less disease. Graph is divided to denote postulated host-pathogen interactions representing susceptible (S), moderately susceptible (MS), moderately resistant (MR), and resistant (R) reactions. Separation of $R$ and MR categories is based on infection incidence only. Separation of MS and $\mathrm{S}$ categories is based upon the rate of pathogen penetration into potato tubers. Refer to Table 2 for details of $P$. nicotianae isolates. Each data point is the mean of four replications in each of two trials. 
Russet Burbank. However, this isolate, as well as other weakly aggressive isolates, proved moderately to highly aggressive on wounded tubers when inoculated as zoospores or mycelium (data not published). These observations are consistent with results obtained previously (41), where the ability of $P$. nicotianae isolates recovered from potato to infect tubers of five potato cultivars was greatly enhanced by inoculating wounded versus nonwounded tuber tissue. It is possible that weakly aggressive $P$. nicotianae strains originating from nonpotato hosts could be opportunistic and more aggressive as wound pathogens than on healthy, nonwounded tubers. This could be explored in future studies. The lower level of aggressiveness observed for $P$. nicotianae strains recovered from nonpotato hosts in this study suggests that these strains may pose less of a threat to potato production than strains established as potato pathogens. Therefore, growers probably should be more concerned about preventing spread of the pathogen from fields with $P$. nicotianae infestations than from alternative host species. Since viable and pathogenic isolates of $P$. nicotianae were recovered from irrigation water in this study, this potential source of inoculum should be considered when assessing inter- and intrafield spread of the pathogen.

Prior work (41) demonstrated significant differences in susceptibility to $P$. nicotianae among one red-, two white-, and two russetskinned potato cultivars. Similarly, significant differences were observed in this study among 27 cultivars representing these phenotypic groups. Cultivar susceptibility to $P$. erythroseptica has been shown to vary greatly within each of these phenotypic groups (33). Tuber rot incidence of five potato cultivars inoculated with either $P$. erythroseptica or $P$. nicotianae was significantly correlated (41). Therefore, the significant differences in infection rates observed among cultivars within each phenotypic group in this study were expected. Although some potato cultivars appeared moderately resistant to $P$. nicotianae tuber infections, most genotypes were highly susceptible. Cultivar resistance currently may not play a major role as a management strategy for this pathogen, but results of this study could prove valuable to potato breeders for developing cultivars with enhanced resistance to $P$. nicotianae.

The potato $\mathrm{cv}$. Atlantic initially was described as resistant to "wet rot" (50), and consistently has proven moderately to highly resistant to tuber infections by $P$. erythroseptica zoospores $(33,43,46)$. These and other observations (41) demonstrate that Atlantic also expresses moderate resistance to $P$. nicotianae and could be a source of resistance for developing new germplasm of white-chipping cultivars. Ranger Russet and Umatilla Russet also expressed high levels of resistance to $P$. nicotianae, and in areas where infections by this pathogen have been confirmed in potato crops, particularly where this is a recurring problem, growers might consider planting these cultivars. The cv. Butte is in the lineage of both of these russet cultivars $(21,25)$. Therefore, each of these cultivars could be assessed as parental material for developing cultivars resistant to this pathogen. Future work could explore the role of other host species in disease epidemiology and examine susceptibility of common potato genotypes to foliar blight caused by $P$. nicotianae, which was not evaluated in this study.

P. nicotianae was isolated in 2005 from potato tubers collected in Nebraska that exhibited symptoms similar to pink rot, and in 2006 from potato leaves grown in Nebraska and Texas as well as from infected tubers from Florida (41). A total of 33 isolates was collected at seven locations in four states from 2005 to 2007 from foliar and/or tuber lesions, indicating that $P$. nicotianae was becoming more prevalent as a pathogen of potato. Isolates of $P$. nicotianae collected from infected potato tissues in 2008 to 2010 were characterized in this study. This survey verified the presence of $P$. nicotianae in Texas, Missouri, and Nebraska; and isolates were obtained from additional locations in these states to those reported previously (41). Seven isolates also were collected from natural tuber infections in Michigan, representing the first report of $P$. nicotianae infection of potato in that state.

Based on the geographical range of $P$. nicotianae-infected potato samples collected prior to 2009 , it was hypothesized that this pathogen may be confined to warmer potato production areas (41). However, the pathogen and associated foliar blight and tuber rot are now known to be more prevalent than earlier observations suggested. Foliar blights and tuber rots caused by $P$. nicotianae have not been documented in potato growing areas of the United States located above the 43rd parallel $(3,11,22,26,41)$. Located at $41.96^{\circ} \mathrm{N}$, the confirmation of potato infection by $P$. nicotianae in Michigan represents the northernmost documentation of the disease to date on potato, although only $\sim 56 \mathrm{~km}$ north of the Nebraska site $\left(41.42^{\circ} \mathrm{N}\right)$ in this study. It is not known whether the presence of $P$. nicotianae in potato crops in northern states can be as devastating as occurrences in southern, warmer potato growing areas of the United States.

P. erythroseptica is homothallic and does not produce chlamydospores (6). Oospores are the resting stage and serve as the primary inoculum source for this pathogen. On the other hand, $P$. nicotianae is heterothallic and capable of producing both chlamydospores and oospores, with the former considered the primary inoculum source (6). Evidence suggests that germination of chlamydospores of $P$. nicotianae is inhibited by cold temperatures and enhanced by extended warming periods of high temperatures, with maximum germination occurring after 100 to 150 degree days (expressed in ${ }^{\circ} \mathrm{C}$, cumulative average temperature above a base of $10^{\circ} \mathrm{C}$ ) have accumulated (18). Based upon that study, temperatures of $32^{\circ} \mathrm{C}$ for 5 days may provide optimum conditions for propagule germination. Oospores of $P$. erythroseptica require a long chilling period for germination (28). The effect of soil temperature on germination efficiency of these propagules may influence the geographic distribution of $P$. erythroseptica and $P$. nicotianae. Oospores of $P$. erythroseptica and chlamydospores of $P$. nicotianae germinate via a germ tube which is capable of growing as mycelium or as mycelium terminating in sporangia, both of which may remain viable in the soil for at least 4 years $(6,28)$. Therefore, although survival of $P$. erythroseptica and $P$. nicotianae is dependent upon the specific propagules produced by each species, the functionality of these propagules appears comparable.

The etiologies of P. erythroseptica pink rot in tubers and $P$. nicotianae tuber rot generally appear to be similar; therefore, practices commonly implemented to manage pink rot should be effective against $P$. nicotianae $(6,13,16,36)$. It is important for potato growers to avoid soil compaction, plant in well-drained soils, and avoid excessive irrigation, particularly toward the end of the growing season. Proper periderm development should be promoted by allowing sufficient time between vine killing and harvest. Harvest and tuber handling procedures should be adjusted to minimize tuber damage. Fungicides, particularly mefenoxam (metalaxyl), augment these agronomic management strategies. The phenylamide fungicide mefenoxam (Ridomil Gold EC and Ultra Flourish EC) has been the only fungicide used to manage pink rot in potato for many years $(23,24,30,36,49,51,52)$, and remains an effective tool for controlling $P$. erythroseptica in populations sensitive to the fungicide $(13,42,44)$. Metalaxyl also is highly toxic to $P$. nicotianae (39). However, metalaxyl-resistant strains of $P$. nicotianae have been recovered from other host species, particularly herbaceous annuals grown in nurseries where the fungicide often is used repeatedly $(7,8,14,15)$. To our knowledge, all isolates of $P$. nicotianae recovered from potato to date have been sensitive to mefenoxam, with sensitivities similar to those reported for isolates not previously exposed to the fungicide (38). Currently, the threat of resistant strains moving from nonhost species to potato crops is limited, as the level of aggressiveness exhibited by the two metalaxyl-resistant isolates recovered from tobacco and lavender in this study was very low and similar to that of metalaxyl-sensitive isolates recovered from nonpotato hosts. Mefenoxam has been employed successfully to prevent significant economic losses in commercial potato production fields where $P$. nicotianae infections have been confirmed (unpublished data), and should continue to provide effective control of tuber rot by this pathogen. However, care should be taken by growers to minimize the possibility of mefenoxam resistance developing in potato $P$. nicotianae populations. 
In areas where $P$. nicotianae is likely to be present, the scarcity of reports of the pathogen infecting potato may be due, in part, to low levels of infection in fields. As with other oomycete tuber rot pathogens, infections usually are detected in low-lying areas; in areas with compacted, poorly drained soil; and along irrigator wheel tracks. In addition, P. nicotianae infections sometimes may be misdiagnosed. Symptoms of tuber rot differ subtly from those of pink rot caused by $P$. erythroseptica, and foliar blight caused by $P$. nicotianae can be confused with symptoms of late blight caused by $P$. infestans (41). It is imperative that growers be aware of these factors, particularly since incidences of $P$. nicotianae infections can be relatively low.

Among the 110 isolates of $P$. nicotianae recovered from potato and characterized to date by the authors of this study, nearly all have been of the A 2 mating type. The presence of both the A 1 and A2 mating types previously was verified at a single location in Nebraska (41), and now at a single location in Texas. The presence of the A1 mating type in Nebraska was reconfirmed in 2010. Although inoculation studies demonstrated that the A1 mating type is capable of infecting potato tubers, A1 isolates only have been recovered from leaf/petiole infections in fields. While production of oospores is important for long-term survival as well as a source of soilborne inoculum of many Phytophthora species, the scarcity of populations comprised of mixed mating types of $P$. nicotianae suggests that chlamydospores may be important survival structures of this pathogen in most potato growing areas where the pathogen has been found. In the two locations in this study where the $P$. nicotianae population comprised both mating types, oospores could afford an additional means of survival but, more importantly, provide a means of sexual reproduction and genetic recombination. If mefenoxam routinely is used to control $P$. nicotianae infections of potato in these areas, the possibility of resistance developing to the fungicide is amplified by the presence of both mating types. The sensitivity of the pathogen populations to mefenoxam should be assessed regularly in these locations.

Information regarding potato cultivar susceptibility to $P$. nicotianae, $P$. nicotianae isolate pathogenicity or aggressiveness on potato, and mefenoxam sensitivity of $P$. nicotianae isolates, as described in this study should prove valuable to potato breeders and growers for developing strategies for managing P. nicotianae. Recent research has added significantly to knowledge of this pathogen, but additional work is needed, including research on the etiology and epidemiology of the disease, and how various factors impact spatial and temporal distribution of the pathogen in potato production regions.

\section{Acknowledgments}

We thank Dean Peterson and Roberta Sherman for their invaluable technical assistance with the postharvest challenge inoculation studies. We also acknowledge the excellent technical assistance of Arlene Mendoza-Moran in mating type and isolate characterization studies, as well as Curt Doetkott and Yanchun Zhao for assistance with statistical analyses. We also extend our thanks and appreciation to Robert Mulrooney, University of Delaware, and Chuanxue Hong, Virginia Polytechnic Institute and State University, for providing some of the isolates used in these studies.

\section{Literature Cited}

1. Bonde, R. 1938. The occurrence of pink-rot and wilt in Maine. Plant Dis. Rep. 22:460.

2. Bush, E. A., Hong, C., and Stromberg, E. L. 2003. Fluctuations of Phytophthora and Pythium spp. in components of a recycling irrigation system. Plant Dis. 87:1500-1506.

3. Cairns, H., and Muskett, A. E. 1933. Pink rot of the potato. Ann. Appl. Biol. 20:381-403.

4. Drechsler, C. 1929. A diplanetic species of Phytophthora causing pink rot of potato tubers. Phytopathology 19:92.

5. Ersek, T., Schoelz, J. E., and English, J. T. 1994. PCR amplification of species-specific DNA sequences can distinguish Phytophthora species. Appl. Environ. Microbiol. 60:2616-2621.

6. Erwin, D. C., and Ribeiro, O. K. 1996. Phytophthora Diseases Worldwide. American Phytopathological Society, St. Paul, MN.

7. Ferrin, D. M., and Kabashima, J. N. 1991. In vitro insensitivity to metalaxyl of isolates of Phytophthora citricola and P. parasitica from ornamental hosts in southern California. Plant Dis. 75:1041-1044.
8. Ferrin, D. M., and Rohde, R. G. 1992. In vitro expression of resistance to metalaxyl by a nursery isolate of Phytophthora parasitica from Catharanthus roseus. Plant Dis. 76:82-84.

9. Fry, W. E., Thurston, H. D., and Stevenson, W. R. 2001. Late blight. Pages 28-30 in: Compendium of Potato Diseases, 2nd ed. W. R. Stevenson, R. Loria, G. D. Franc, and D. P. Weingartner, eds. American Phytopathological Society, St. Paul, MN.

10. Gallegly, M. E., and Hong, C. 2008. Phytophthora - Identifying Species by Morphology and DNA Fingerprints. American Phytopathological Society, St. Paul, MN

11. Goss, R. W. 1949. Pink rot of potato caused by Phytophthora erythroseptica Pethyb. Univ. Nebr., College Agric., Agric. Exp. Stn., Lincoln, NE. Res. Bull. 160.

12. Grisham, M. P., Taber, R. A., and Barnes, L. W. 1983. Phytophthora rot of potatoes in Texas caused by Phytophthora parasitica and P. cryptogea. Plant Dis. 67:1258-1261.

13. Gudmestad, N. C., Taylor, R. J., and Pasche, J. S. 2007. Management of soilborne diseases of potato. Australas. Plant Pathol. 36:109-115.

14. Hu, J. H., Hong, C. X., Stromberg, E. L., and Moorman, G. W. 2008. Mefenoxam sensitivity and fitness analysis of Phytophthora nicotianae isolates from nurseries in Virginia, USA. Plant Pathol. 57:728-736.

15. Hwang, J., and Benson, D. M. 2005. Identification, mefenoxam sensitivity, and compatibility type of Phytophthora spp. attacking floriculture crops in North Carolina. Plant Dis. 89:185-190.

16. Lambert, D. H., and Salas, B. 2001. Pink rot. Pages 33-34 in: Compendium of Potato Diseases, 2nd ed. W. R. Stevenson, R. Loria, G. D. Franc, and D. P. Weingartner, eds. American Phytopathological Society, St. Paul, MN.

17. Lonsdale, D., Cunliffe, C., and Epton, H. A. S. 1980. Possible routes of entry of Phytophthora erythroseptica Pethyb. and its growth within potato plants. Phytopathol. Z. 97:109-117.

18. Lutz, A. L., Menge, J. A., and Ferrin, D. M. 1991. Increased germination of propagules of Phytophthora parasitica by heating citrus soils sampled during winter. Phytopathology 81:865-872.

19. MacNish, G. C. 1968. Pink rot of potatoes in Western Australia. Plant Dis Rep. 52:280.

20. Millikin, G. A., and Johnson, D. E. 1992. One-way treatment structure in a completely randomized design with heterogeneous errors. Pages 16-28 in: Analysis of Messy Data, Vol. 1. Designed Experiments, Chapman and Hall, London.

21. Mosley, A. R., James, S. R., Hane, D. C., Rykbost. K. A., Shock, C. C., Charlton, B. A., Pavek, J. J., Love, S. L., Corsini, D. L., and Thornton, R. E. 2000. Umatilla Russet: A full season long russet for processing and fresh market use. Am. J. Potato Res. 77:83-87.

22. Mulrooney, R. P., Carroll, R. B., Morehart, A. L., and Wittington, D. P. 1994. Potato pink rot in Delaware and New Jersey caused by Phytophthora nicotianae. Phytopathology 84:546.

23. Mulrooney, R. P., and Gregory, N. F. 2001. Evaluation of foliar and soil applied fungicides for the control of pink rot of potato, 2000. Fungic. Nematicide Tests 56:49.

24. Mulrooney, R. P., and Gregory, N. F. 2002. Evaluation of foliar and soil applied fungicides for the control of pink rot of potato, 2001. Fungic. Nematicide Tests 57:66.

25. Pavek, J. J., Corsini, D. L., Love, S. L., Hane, D. C., Holm, D. G., Iritani, W. M., James, S. R., Martin, M. W., Mosley, A. R., Ojala, J. C., Stanger, C. E., and Thornton, R. E. 1992. Ranger Russet: A long russet potato variety for processing and fresh market with improved quality, disease resistance, and yield. Am. Potato J. 69:483-488.

26. Person, L. H., and Nielsen, L. W. 1969. Potato blight caused by Phy tophthora parasitica in North Carolina. (Abstr.) Phytopathology 59:117.

27. Pethybridge, G.-H. 1913. On the rotting of potato tubers by a new species of Phytophthora having a method of sexual reproduction hitherto undescribed. Sci. Proc. Roy. Dublin Soc. 13:529-565.

28. Pethybridge, G.-H. 1914. Further observations on Phytophthora erythroseptica Pethyb. and on the disease produced by it in the potato plant. Sci. Proc. Roy. Dublin Soc. 14:179-198.

29. Platt, H. W., and Peters, R. D. 2001. Gray mold. Pages 26-28 in: Compendium of Potato Diseases, 2nd ed. W. R. Stevenson, R. Loria, G. D. Franc, and D. P. Weingartner, eds. American Phytopathological Society, St. Paul, MN.

30. Powelson, M. L., Johnson, K. B., and Rowe, R. C. 1993. Management of diseases caused by soilborne pathogens. Pages 149-158 in: Potato Health Management. R. C. Rowe, ed. American Phytopathological Society, St. Paul, MN.

31. Rowe, R. C., and Schmitthenner A. F. 1977. Potato pink rot in Ohio caused by Phytophthora erythroseptica and P. cryptogea. Plant Dis. Rep. 61:807810 .

32. Salas, B., and Secor, G. A. 2001. Leak. Pages 30-31 in: Compendium of Potato Diseases, 2nd ed. W. R. Stevenson, R. Loria, G. D. Franc, and D. P. Weingartner, eds. American Phytopathological Society, St. Paul, MN.

33. Salas, B., Secor, G. A., Taylor, R. J., and Gudmestad, N. C. 2003. Assessment of resistance of tubers of potato cultivars to Phythophthora erythroseptica and Pythium ultimum. Plant Dis. 87:91-97.

34. Salas, B., Stack, R. W., Secor, G. A., and Gudmestad, N. C. 2000. Effect of temperature, wounding and inoculum density on the development of pink 
rot caused by Phytophthora erythroseptica. Plant Dis. 84:1327-1333.

35. SAS Institute Inc. 2010. SAS/STAT User's Guide, Version 9.22. SAS Institute, Cary, NC.

36. Secor, G. A., and Gudmestad, N. C. 1999. Managing fungal diseases of potato. Can. J. Plant Pathol. 21:213-221.

37. Secor, G. A., and Salas, B. 2001. Fusarium dry rot and Fusarium wilt. Pages 23-25 in: Compendium of Potato Diseases, 2nd ed. W. R. Stevenson, R. Loria, G. D. Franc, and D. P. Weingartner, eds. American Phytopathological Society, St. Paul, MN.

38. Shew, D. 1985. Response of Phytophthora parasitica var. nicotianae to metalaxyl exposure. Plant Dis. 69:559-562.

39. Staub, T. H., and Young, T. R. 1980. Fungitoxicity of metalaxyl against Phytophthora parasitica var. nicotianae. Phytopathology 70:797-801.

40. Stevenson, W. R., Loria, R., Franc, G. D., and Weingartner, D. P., eds. 2001. Compendium of Potato Diseases, 2nd ed. American Phytopathological Society, St. Paul, MN.

41. Taylor, R. J., Pasche, J. S., Gallup, C. A., Shew H. D., and Gudmestad, N. C. 2008. A foliar blight and tuber rot of potato caused by Phytophthora nicotianae: New occurrences and characterization of isolates. Plant Dis. 92:492-503.

42. Taylor, R. J., Pasche, J. S., and Gudmestad, N. C. 2006. Biological significance of mefenoxam resistance in Phytophthora erythroseptica and its implications for the management of pink rot of potato. Plant Dis. 90:927-934.

43. Taylor, R. J., Pasche, J. S., and Gudmestad N. C. 2008. Susceptibility of eight potato cultivars to tuber infection by Phytophthora erythroseptica and Pythium ultimum and its relationship to mefenoxam-mediated control of pink rot and leak. Ann. Appl. Biol. 152:189-199.

44. Taylor, R. J., Salas, B., and Gudmestad, N. C. 2004. Differences in etiology affect mefenoxam efficacy and the control of pink rot and leak tuber diseases of potato. Plant Dis. 88:301-307.

45. Taylor, R. J., Salas, B., Secor, G. A., Rivera, V., and Gudmestad, N. C. 2002. Sensitivity of North American isolates of Phytophthora erythroseptica and Pythium ultimum to mefenoxam (metalaxyl). Plant Dis. 86:797802.

46. Thompson, A. L., Taylor, R. J., Pasche, J. S., Novy, R. G., and Gudmestad, N. C. 2007. Resistance to Phytophthora erythroseptica and Pythium ultimum in a potato clone derived from S. berthaultii and S. etuberosum. Am. J. Potato Res. 84:149-160.

47. Thurston, H. D. 2001. Origin, history and importance of the potato. Pages 1-2 in: Compendium of Potato Diseases, 2nd ed. W. R. Stevenson, R. Loria, G. D. Franc, and D. P. Weingartner, eds. American Phytopathological Society, St. Paul, MN.

48. Timmer, L. W., Graham, J. H., and Zitco, S. E. 1998. Metalaxyl-resistant isolates of Phytophthora nicotianae: Occurrence, sensitivity and competitive parasitic ability on citrus. Plant Dis. 82:254-261.

49. Torres, H., Martin, C., and Henfling, J. 1985. Chemical control of pink rot of potato (Phytophthora erythroseptica Pethyb.). Am. Potato J. 62:355-361.

50. Webb, R. E., Wilson, D. R., Shumaker, J. R., Graves, B., Henninger, M. R. Watts, J., Frank, J. A., and Murphy, H. J. 1978. Atlantic: A new potato variety with high solids, good processing quality and resistance to pests. Am. Potato J. 55:141-145.

51. Wicks, T. J., Davoren, C. W., and Hall, B. H. 2000. Fungicidal control of Phytophthora erythroseptica: The cause of pink rot on potato. Am. J. Potato Res. 77:233-240.

52. Zink, R. T. 1995. The effect of metalaxyl on the incidence of pink rot. (Abstr.) Am. Potato J. 72:665-666. 